\title{
Can drug compliance in the elderly be improved?
}

\author{
I WANDLESS, J W DAVIE
}

British Medical fournal, 1977, 1, 359-361

\section{Summary}

Three instruction schemes for self-medication in older patients were designed and compared to see whether they improved drug compliance. Forty-six patients in two rehabilitation units were divided into three different groups. Each group was instructed verbally on the nature and amount of their medication. One group was also given a tear-off calendar and a second group a tablet identification card as a memory aid. Patients were then responsible for taking their own medicine for 14 days. Those with calendars made fewer errors than those with cards, and those with either a card or a calendar made significantly fewer errors than those given only standard instructions.

\section{Introduction}

In prescribing oral medication for use at home we rely on patients to take their prescribed treatment correctly. A survey of 151 patients aged 75 years and over in one general practice showed that $85 \%$ of the patients on regular treatment were responsible for taking their own medicines. ${ }^{1}$ But several studies have shown that over half of elderly patients do not take their drugs as prescribed, ${ }^{2}{ }^{3}$ and the percentage of all patients who make errors is probably between $25 \%$ and $59 \%{ }^{4}$ Many of these patients may not clearly understand their regimens, ${ }^{5}$ and about $4-35 \%$ of patients misuse their drugs to such an extent that they

Stobhill General Hospital, Glasgow G21 3UW

I WANDLESS, MB, MRCP, registrar in geriatric medicine (now senior research associate, Age Research Unit, Newcastle Upon Tyne)

J W DAVIE, DRCOG, MRCP, senior registrar in geriatric medicine

endanger their health. ${ }^{4}$ Perhaps $5 \%$ of the beds in general hospitals in the United Kingdom may be occupied by patients suffering to a greater or less extent from our attempts to treat them. ${ }^{6}$

Because of the size of the problem we decided to examine three methods of patient instruction in self-medication.

\section{Patients and methods}

We studied 46 patients ( 42 women) who were transferred to the rehabilitation units attached to the university department of geriatric medicine. They were aged 64 to 93 years (mean 77 years). They were orientated in time and place, had suitable visual acuity, and were receiving their drugs on a regular and not on an as-required basis (table I).

TABLE I-Characteristics of each group

\begin{tabular}{|c|c|c|c|c|c|}
\hline & $\begin{array}{l}\text { Mean age } \\
\text { and range } \\
\text { in years }\end{array}$ & $\begin{array}{l}\text { Mean length } \\
\text { of stay in } \\
\text { hospital } \\
\text { before trial } \\
\text { and range } \\
\text { in weeks }\end{array}$ & $\begin{array}{c}\text { Mean } \\
\text { mental } \\
\text { test score }\end{array}$ & $\begin{array}{l}\text { Mean No } \\
\text { of bottles } \\
\text { of tablets }\end{array}$ & $\begin{array}{l}\text { Mean No of } \\
\text { tablets for } \\
\text { two weeks }\end{array}$ \\
\hline $\begin{array}{l}\text { Group } 1 \\
\text { Group } 2 \\
\text { Group } 3\end{array}$ & $\begin{array}{l}75(64-86) \\
75(67-83) \\
79(68-93)\end{array}$ & $\begin{array}{l}19(2-70) \\
17(2-52) \\
23(2-70)\end{array}$ & $\begin{array}{l}14.7 \\
15.0 \\
14.5\end{array}$ & $\begin{array}{l}3 \cdot 1 \\
3 \cdot 2 \\
2 \cdot 6\end{array}$ & $\begin{array}{l}96 \\
99 \\
75\end{array}$ \\
\hline
\end{tabular}

We had excluded patients who were prescribed insulin, warfarin, or parenteral preparations; those who could not read the labels on their medicines; and those scoring less than 12 on an intellectual rating scale with a maximum of $17 .{ }^{7}$ Those who scored 12 or more were considered to be able to manage alone at home.

After the patients had given their informed written consent they were allocated on a random number basis to one of three groups and were each given two weeks' supply of their usual medication. All tablets were dispensed in clear glass bottles with screw caps and clearly typed labels giving the usual instructions issued by the 
pharmacy-for example, "Frusemide. Take one in the morning." All patients could manage the screw caps on these bottles.

All the patients were given standard verbal instructions. The purpose of the trial was explained, the tablets were described and shown, and the name and purpose of the tablets and the dose and time of administration were explained. These instructions were briefly summed up, and the patient was asked to repeat them. Patients in group 1 received only the verbal instructions. Patients in group 2 also received a calendar detailing each day's treatment (fig 1). The patient was asked to read over the directions on one page of the calendar and to tear off one page after she had taken each day's tablets. Each patient in group 3 was given the standard instructions plus a card identifying each tablet and detailing the regimen (fig 2). At their initial instruction the patients were asked to read out the directions on their cards.

FIG 1-Example of page from 14-day tear-off calendar.

\begin{tabular}{|c|c|c|}
\hline $\begin{array}{r}\text { Name.. } \\
-------\end{array}$ & Monday, 9 Febr & …… \\
\hline $\begin{array}{l}\text { Tablets } \\
8 \text { am }\end{array}$ & $\begin{array}{l}\text { One frusemide } \\
\text { One digoxin } \\
\text { One Slow K } \\
\text { One ampicillin }\end{array}$ & $\begin{array}{l}\text { (water tablet) } \\
\text { (heart tablet) } \\
\text { (salt tablet) } \\
\text { (antibiotic) }\end{array}$ \\
\hline 12 noon & $\begin{array}{l}\text { One Slow K } \\
\text { One ampicillin }\end{array}$ & \\
\hline $6 \mathrm{pm}$ & $\begin{array}{l}\text { One Slow K } \\
\text { One ampicillin }\end{array}$ & \\
\hline $10 \mathrm{pm}$ & $\begin{array}{l}\text { One Slow K } \\
\text { One ampicillin }\end{array}$ & \\
\hline
\end{tabular}

FIG 2-Example of card given to patients in group 2. Open circles indicate where example of each tablet is fixed to card.

\begin{tabular}{|c|c|}
\hline Name... & $\begin{array}{l}\text { Lanoxin (heart tablet) } \\
\text { Take one at } 8 \text { in the morning }\end{array}$ \\
\hline & $\begin{array}{l}\text { Frusemide (water tablet) } \\
\text { Take one at } 8 \text { in the morning }\end{array}$ \\
\hline & $\begin{array}{l}\text { Slow } \mathrm{K} \text { (salt tablet) } \\
\text { Take one at } 8 \text { in the morning } \\
\text { one at } 2 \text { in the afternoon } \\
\text { one at } 6 \text { in the evening }\end{array}$ \\
\hline
\end{tabular}

The patients in the study were allocated to side wards so that they were not cued by the regular medicine round. They were still asked to keep their tablets in their lockers out of sight of other patients.

They were told that from time to time the number of tablets in their bottles would be checked in case they needed more tablets, and we ensured that they had no objections to this. We checked unobtrusively every two days to note the number of tablets in each bottle, and at the end of two weeks counted the total remaining in each bottle. From the discrepancy between the number of tablets which should have been left at each tablet count and the number actually left we could calculate whether too many or too few tablets had been taken from each bottle. Each tablet too many or too few was counted as one error.

\section{Results}

The total number of tablets to be taken by the 46 patients over two weeks was 4190 . During the course of counting the tablets every 48 hours it became apparent that patients did not consistently either underdose or overdose themselves. Taking too many tablets one day might, purely by chance, be balanced by taking too few the next. Hence the error rates calculated from the tablet counts at the end of 14 days were exceeded in some patients by the error rates calculated from the tablet counts every two days. The number of errors made by the 46 patients at the total count was 756 , but the sum of the two-day count errors was 930 (table II).

TABLE II-Differences between sum of two-day count errors and total count errors

\begin{tabular}{|c|c|c|c|c|c|}
\hline & & $\begin{array}{c}\text { No of } \\
\text { patients } \\
\text { in group }\end{array}$ & $\begin{array}{l}\text { Total No of } \\
\text { tablets }\end{array}$ & $\begin{array}{l}\text { Total count } \\
\text { errors }\end{array}$ & $\begin{array}{l}\text { Sum of } \\
\text { two-day count } \\
\text { errors }\end{array}$ \\
\hline $\begin{array}{l}\text { Group } 1 \\
\text { Group } 2 \\
\text { Group } 3\end{array}$ & $\begin{array}{l}\ldots \\
\cdots\end{array}$ & $\begin{array}{l}15 \\
17 \\
14\end{array}$ & $\begin{array}{l}1428 \\
1716 \\
1046\end{array}$ & $\begin{array}{l}332 \\
236 \\
188\end{array}$ & $\begin{array}{l}402 \\
308 \\
220\end{array}$ \\
\hline
\end{tabular}

Table III shows the range of errors per group expressed as a percentage of possible errors, working on the assumption that one tablet gives a possibility for one error. Nine patients made no mistakes (table IV).

TABLE III-Range of errors for each group expressed as percentage of possible errors

\begin{tabular}{cc|c|c|c} 
& & No in group & $\begin{array}{c}\text { Range of two-day } \\
\text { count errors }\end{array}$ & $\begin{array}{c}\text { Range of total } \\
\text { count errors }\end{array}$ \\
\hline Group 1 & $\cdots$ & 15 & $0-77$ & $0-71^{*}$ \\
Group 2 & $\cdots$ & 17 & $0-77$ \\
Group 3 & $\cdots$ & 14 & $0-70^{*}$ \\
\hline
\end{tabular}

*One patient.

TABLE IV-Characteristics of patients who made no mistakes

\begin{tabular}{|c|c|c|c|c|c|}
\hline $\begin{array}{l}\text { Case } \\
\text { No }\end{array}$ & Age and sex & $\begin{array}{c}\text { Mental test } \\
\text { score }\end{array}$ & $\begin{array}{l}\text { No of } \\
\text { tablets for } \\
\text { two weeks }\end{array}$ & $\begin{array}{l}\text { No of } \\
\text { bottles of } \\
\text { tablets }\end{array}$ & Group \\
\hline $\begin{array}{l}1 \\
2 \\
3 \\
4 \\
5 \\
6 \\
7 \\
8 \\
9\end{array}$ & $\begin{array}{ll}75 & \mathrm{~F} \\
70 & \mathrm{~F} \\
75 & \mathrm{~F} \\
77 & \mathrm{~F} \\
80 & \mathrm{~F} \\
76 & \mathrm{~F} \\
70 & \mathrm{~F} \\
88 & \mathrm{~F} \\
69 & \mathrm{M}\end{array}$ & $\begin{array}{l}16 \\
16 \\
16 \cdot 5 \\
17 \\
17 \\
17 \\
13 \cdot 5 \\
14 \\
16\end{array}$ & $\begin{array}{r}42 \\
196 \\
112 \\
112 \\
56 \\
28 \\
14 \\
14 \\
14\end{array}$ & $\begin{array}{l}1 \\
6 \\
4 \\
4 \\
1 \\
2 \\
1 \\
1 \\
1\end{array}$ & $\begin{array}{l}2 \\
2 \\
2 \\
2 \\
2 \\
3 \\
3 \\
3 \\
1\end{array}$ \\
\hline
\end{tabular}

Applying the $\chi^{2}$ test to the results in table II, using a reduction in errors as a goal, showed that for total count errors group 2 was significantly better than group $1 \quad(P<0.0005)$, group 3 was significantly better than group $1(P<0.005)$, and group 2 was significantly better than group $3(P<0 \cdot 01)$. For two-day count errors group 2 made significantly fewer errors than group $1(P<0.0005)$, group 3 significantly fewer than group $1(P<0 \cdot 0005)$, and group 2 fewer than group 3 but not significantly fewer $(P<0 \cdot 10)$. Considering the groups as a whole, patients who were given an aid to memory in the form of a card or a calendar made fewer mistakes in their tablet taking.

\section{Discussion}

The total number of drugs prescribed for the elderly population is higher than that for younger age groups: the elderly, who represent only about $12 \%$ of the population, are responsible for about $30 \%$ of the National Health Service expenditure on prescriptions. ${ }^{8}$ Thus elderly patients are often expected to comply with complicated schedules for several drugs. ${ }^{19}$

The patients included in our study had reasonable visual acuity, were orientated in time and place, and received their tablets in manageable containers with typed labels. Nevertheless, those who were given standard verbal instructions, which were 
more detailed than those that are sometimes given to patients on discharge from hospital, had an error rate on two-day counts of $28^{\circ} \mathrm{o}$. Those who erred were more likely to make multiple rather than single mistakes. This could be potentially seriousfor example, with the combination of drugs given for treating heart diseases-namely, diuretics, potassium supplements, and cardiac glycosides.

Malahy found that giving planned instructions and labelling the medication with the drug name did not significantly reduce the number of errors, nor did the particular form of teaching used. ${ }^{10}$ In contrast, we found that the number of errors was significantly reduced when patients were given a written aid to memory as well as verbal instructions, although some patients in all groups had substantial error rates (see table III). Allowing for exceptions, our findings indicate that drug compliance in the elderly can be improved by giving patients written as well as verbal instructions.

We think that it would be valuable to extend this study by following up patients discharged from hospital to confirm that a written memory aid, particularly a calendar, can improve drug compliance.
We thank Mr S Bryson, pharmacy department, Stobhill General Hospital, for dispensing the drugs; Mr Strachan, Miss Macleod, and the rest of the nurses at Birdston and Lenzie Hospitals and the rehabilitation units for their co-operation; $\operatorname{Dr} \mathrm{R} \mathrm{D}$ Kennedy and Dr R H Al-Badran for permission to include their patients in the study; and Mr G Pye for help with the statistics.

\section{References}

1 Law, R, and Chalmers, C, British Medical fournal, 1976, 1, 565

2 Gibson, I I J M, and O'Hare, M M, Gerontologia Clinica, 1968, 10, 271

3 Schwartz, D, et al, American fournal of Public Health, 1962, 52, 2018.

- Stewart, R B, and Cluff, L E, Clinical Pharmacology and Therapeutics, $1972,13,463$.

5 Parkin, D M, et al, British Medical fournal, 1976, 2, 686.

${ }^{6}$ Dunlop, D, British Medical fournal, 1969, 2, 622.

7 Robinson, R A, in Assessment in Cerebrovascular Insufficiency, p 89. Stuttgart, Georg Thieme Verlag, 1971.

${ }^{8}$ Crooks, J, Health Bulletin, 1975, 33, 222.

9 Shaw, S M, and Opit, L J, British Medical fournal, 1976, 1, 507.

${ }^{10}$ Malahy, B, American fournal of Hospital Pharmacy, 1966, 23, 283.

(Accepted 25 November 1976)

\title{
Occasional Review
}

\section{Clinical trials of the treatment of breast cancer in Britain and Ireland}

\author{
Report by Co-ordinating Committee*
}

British Medical fournal, 1977, 1, 361-364

\section{Summary}

Thirteen trials of systemic chemotherapy in early breast cancer were identified and protocols obtained. The differences in the latter prevented a true comparison of the results. In setting up any trial it is important to define the primary objectives and to include a statistician from the start. Only truly random allocation of patients is acceptable, while treatment programmes must be fully monitored. Other important aspects include review of the results by an independent member of the trial committee and keeping full, but simple, case records. Though any trial must be designed by a committee and not a single investigator, the individual clinician remains responsible for the patients under his care.

To launch a controlled randomised trial without full preparation and guaranteed resources is in the best interests of neither patients nor doctors.

*Members of the Committee were: A P M Forrest (chairman), N M Bleehen Diana Brinkley, A R Currie, K Griffiths (Tenovus representative), J I Hayward, J G Murray, M J O'Halloran, $R$ Peto, $R$ Raven (ICRF representative), $R$ A Sellwood, T Vickers (MRC observer), R J Wrighton (DHSS observer), Helen J Stewart, and N H Kemp (secretariat).

\section{Introduction}

After the publication of the results of the trials of systemic chemotherapy in early breast cancer, ${ }^{12}$ we obtained information through departments of surgery, radiotherapy, and oncology of existing or projected controlled trials designed to examine the value of this form of treatment in Britain. Thirteen trials were identified and protocols were obtained (table).

Differences in these protocols will, with two possible exceptions, prevent a true comparison of the results. These differences concerned the objectives and designs of the studies, the therapeutic agents to be used, the methods of selection of patients for the trials, and the type of local treatment.

We know that further trials are being discussed and, with the hope of promoting greater uniformity of design, we present a series of guidelines modified from the International Union Against Cancer technical report. ${ }^{3}$ If they were to be followed better comparability and even integration of future results might be possible.

Although initiated by the current interest in additional systemic chemotherapy, these guidelines apply equally to all controlled therapeutic studies in patients with early breast cancer.

\section{Definition and purpose of a trial}

The primary objectives of a trial must be precisely defined. Secondary objectives may also be included, but these are less critical to the design of a trial and should not lead to undue complication. A 